\title{
The Effective Research about New Media Promotes the Art Students to Study the Ideological and Political Theory
}

\author{
BAI Bing, QIN Mao Lin \\ Wuhan University of Science and Technology, Wuhan 430070, China \\ xuexi123@163.com
}

Keywords: New Media;art students; study the ideological and political theory; the effective research

\begin{abstract}
The New Media promotes the development of the work in ideological and political education, which makes an extensive and profound influence about the growth of college students to success. The author(this article combines working practice with deep thinking and research the effectiveness of New Media for art students to study the ideological and political theory. It starts from the characteristics of the New Media and art students to analyze the advantages and disadvantages of the traditional education. What's more, it also summarizes the feasibility countermeasures of networking educational content and forms, networking the educational ways, improving the ability of grasping the New Media, the improvement of the mechanism of supervision and management and so on, in studying creative politics theory to look forward to improve the effectiveness of the art students of studying the ideological and political theory under the New Media era.
\end{abstract}

\section{Introduction}

The well-known American futurologist Alwen Toffler has pointed out : "The people who has mastered the information and controlled the network will own the world."[1] The sixth plenary session of the 17th communist party congress passed 《Several major issues further the reform of cultural system to promote great development of socialist culture prosperity by the central committee of the communist party of China》.It points out that it is an urgent task for the construction of socialist culture to strengthen the construction of online ideology and culture. The policy must be earnestly implemented, actively used, scientifically developed, legally managed and securely guaranteed. And we also need to enhance the establishment and management of web culture and the guiding of public opinion in the net for making online cultural theme.

In this highly informational age, the Internet plays an important role in spreading the mainstream ideology of their countries. And yet aspects of today's new online media, differing in form from earlier innovations (and even from the internet's own earliest manifestations) can also be expected to differ in their impacts [2]. So that the ideological and political education in universities are faced with unprecedented challenges, especially the work of Party Constructions. We ought to make the best use of new communication carriers and promote our work.

\section{Definition and features of New Media}

The definition of New Media: New Media is not only a media form under the new technical support system but also a new media following the newspapers, television, radio and other traditional media, which include the Internet, mobile phone platform, multimedia digital media and so on. Because linked to university students closely, New Media is gradually changing their learning, life, way of thinking and values [3] .Compared with the traditional media, it has the following characteristics: It has a lot of information and it is open. This large and extensive information not only greatly enrich the ideological and political education resources, but also can make the ideological and political education timely to improve the effectiveness of ideological and political education [4]. The ideology behind the New Media is the biggest challenge of ideological and political education because of its freedom and openness. It is virtual and concealed. Network technology can realize the virtual communication. Its concealment provides the space for people to 
show their inner world. It is reported that they tend to become more easily selfish and indifferent, not concern about the collective, or don't care about others.

It has an interactivity and timeliness. Under the New Media environment, the transmission of information is not limited, it is fully covered and timely, and the information is interactive, not a one-way one. Students can search and choose any favorite information because the channels and resources are various. Political education work in higher education centers on ensuring students' political reliability[5]. New Media have so many characteristics above that it will have a great impact on thought and value. It is more enormous impact on the work in ideological and political education.

\section{The characteristics of art students}

Art students' professional thinking are always active, but thinking and value is not mature enough. Because their professional amount of specificity, their personalities are particularly vivid. Art is different from the general technology, which emphasizes more on rigorous. Ideological work (formally called ideological-political work) is supposed to provide spiritual support for socialism and communism, attempting not only to determine people's political standing and behavior, but also to construct their worldview, life philosophy and value orientations[6].we need to carefully organize the ideological and political education with the right outlook, values which are used to guide students to make students understand the social and gain social integration, and cultivate students' responsibility of the society in dedication. The most important part is that art students have little collective consciousness. One reason is that art education always concentrates on personalized development. They have strong self-consciousness, which is performed as no collective concept, liberal, doing things themselves and not obeying the management.

They regard as important in art practice, think little the theory of learning and so on. Art majors attach more importance to study, but they only think high of their professional courses, and they take particular stress on professional skill to master, not in culture, especially in political and theoretical subject that they hate. Some students' culture is superficial.

\section{The present situation of studying the traditional ideological and political theory}

The model of education is boring and its form is single. And the form of the ideological and political education is persuasion and education, which is ignorant in the university students' psychological characteristics. The disadvantage is that the content of education is unreasonable, the pertinence of content is not strong, and practicalness is weak. The waste of manpower and material resources is serious. The reason why educational measures can not be taken well is that now the activities of ideological and political education in art students are lack of initiative, pertinence and timeliness, the concept of education is out of fashion and it can not be consistent with the pertinence of ideological and political education of art students in new situation whose profound and persistence can not be achieved. It ignores individual differences. Traditional ideological and political education takes the same mode, which is centralized organization, focused on learning, focused on education and ignores students' differences as an individual. As art students, parental style of education can't suit students' psychological need obviously. It doesn't have strong association with reality. The mode of traditional ideological education limits the work of ideological and political education to be closed environment in colleges and can't exercise and educate students by contacting social positively, using modern technical means like internet and participating social practice effectively in order to educate students.

\section{The effective research about the New Media's application}

The New Media has brought about the reform of educational work, study and communication. It provides the effective mode for modern education and innovation. We must strengthen the construction of the educational website; realize the network of the content and form of the party 
construction. Educational website is the most important New Media carrier for college students' party members' education. To improve the educational effect, we should build the boutique red website which students like, active concern, understand and easy to learn. For example, Tsinghua University's party construction network, which is rich in content, has become an important base of ideological and political education[7]. We must establish electronic publications for college students, rich the channels of transmission about the contents of party construction. Conditional Universities can open the micro-blog for party construction of student. In addition, micro-blog can also be used to achieve scientific management of mobile party members. The establishment of We Chat and faction group, the full use of mobile phones can timely release of information within the party, send relevant notice and various information to party members of students. Network of education and management for Party members' development. Exchange platform can be constructed for red theme. The system of management and actual situation of party members in modern university decide that the chance of the concentrated training education is very limited. In order to further strengthen the management of party members, especially the senior and migrant members. The most effective way is to use platforms of New Media to exchange information timely. Core values may be chronically accessible, rendering them easily activated by media frames[8]. Improving the literacy and ability of New Media. With the rapid development of New Media, information flooding, privacy leakage, internet addiction and other serious social issues are arise. To set up the team which has firm politics, proficient in business, qualified personnel to guarantee the ideal and belief education. The team should have a profound theoretical level, a strong sense of responsibility, rich party construction work by experience, skilled level of network technology and the ability, and so on. Carry out the mechanism of supervision Firstly, all kinds of effective rules and regulations should be made and be carried out to make sure discover every kind of harmful information in time to take actions and give guidance correctly.Secondly, it's also important to strengthen the education which is the university students' morality of internet, network ethic and internet laws. Therefore, it can regulate their performances on internet, improving their ability of identification and controlling on internet.

\section{Summary}

With the development of the times and science, people who are in charge of ideological and political education should be fully aware of the importance of New Media, take the initiative to learn the symptom of New Media, combine the university students' features to continue innovating the model of work and cultivating the new carrier for party construction, push the party construction of colleges and universities to be carried out persistently and deep.

\section{References}

[1] Zheng Yuanjing. Analysis on the Effectiveness of Ideological and Political Education of University under the New Media Environment[J]. The Tribune of Ideological and Theoretical Education,2011,(11)

[2] MEREDITH L. WEISS. Parsing the Power of "New Media" in Malaysia. Journal of Contemporary Asia, 2013,Vol. 43, No. 4:591 - 612

[3] Zhang Lei. Reflections on the Validity of Spread about Ideological and Political Education of University under the New Media Environment[J].Schools Party Construction and Ideological Education, 2013(1)12-18.

[4] Wang Yuan, Ding Zhenguo. The Discussion about Strengthening the Effectiveness of Ideological and Political Education of University in the Internet Age[J]. Schools Party Construction and Ideological Education, 2009(8) 12-18. 
[5] QINGHUA WANG. Strengthening and Professionalizing Political Education in China's Higher Education. Journal of Contemporary China, 2013,Vol. 22, No. 80:332 - 350

[6] Li Maosen.Changing ideological-political orientations in Chinese moral education: some personal and professional reflections. Journal of Moral Education,2011,Vol. 40, No. 3:387 - 395

[7] Zhou Yong. The Discussion about Long-term Mechanism Construction of Ideal and Faith Education on Party Members of College Students under the New Media Environment[J].Time Report(Academic), 2013(9) 12-18.

[8] Price V, Tewksbury D. (1997) News values and public opinion: A theoretical account of media priming and framing. In Barnett G, Boster FJ, eds. Progress in the Communication Sciences. New York: Ablex. 